\title{
LATE ONSET TEMPORAL LOBE EPILEPSY WITH MRI EVIDENCE OF MESIAL TEMPORAL SCLEROSIS FOLLOWING ACUTE NEUROCYSTICERCOSIS
}

\section{Case report}

\author{
Eliane Kobayashi, Carlos A.M. Guerreiro, Fernando Cendes
}

\begin{abstract}
The objective of this case report is to describe magnetic resonance imaging (MRI) evidence of mesial temporal sclerosis (MTS) in a patient with new onset temporal lobe epilepsy (TLE) and acute neurocysticercosis with multiple cysts. A 56 years old man with new onset headache, Simple Partial Seizures and Complex Partial Seizures underwent CT scan and lumbar puncture as diagnose proceeding. Multiple cysts and meningitis were identified, with a positive immunology for cysticercosis. Seizures were recorded over the left temporal region in a routine EEG. Treatment with albendazole was performed for 21 days, with clinical improvement and seizure remission after 4 months. An MRI scan 11 months after treatment, showed complete resolution of those cystic lesions and a left hippocampal atrophy (HA) with hyperintense $T 2$ signal. The presence of HA and hyperintense T2 signal in this patient has not, to date, been associated with a poor seizure control. Conclusions: This patient presented with MRI evidence of left MTS after new onset partial seizures of left temporal lobe origin. Although we did not have a previous MRI scan, it is likely that this hippocampal abnormality was due to the acute inflammatory response to cysticercosis associated to repeated partial seizures. This suggests that acute neurocysticercosis associated with repeated seizures may cause MTS and late onset TLE.
\end{abstract}

KEY WORDS: temporal lobe epilepsy, hippocampal atrophy, mesial temporal sclerosis, acute neurocysticercosis.

\begin{abstract}
Epilepsia de lobo temporal de início tardio com evidências de esclerose mesial temporal após quadro agudo de neurocisticercose: relato de caso

RESUMO - O objetivo deste relato é descrever a evidência de esclerose mesial temporal (EMT) por ressonância magnética (RM) em um paciente com epilepsia de lobo temporal (ELT) de início tardio e múltiplos cisticercos. Um paciente de 56 anos previamente hígido, iniciou quadro de cefaléia, crises parciais simples e complexas, sendo realizadas TC de crânio e punção lombar. Foram visualizados múltiplos cistos e meningite com imunologia positiva para cisticercose. Registramos crises com início em região temporal esquerda durante um eletroencefalograma de rotina. Iniciamos tratamento com albendazol, por 21 dias, e observamos melhora clínica e remissão de crises após 4 meses. RM feita 11 meses após o tratamento mostrou resolução completa das lesões císticas e uma atrofia hipocampal $(\mathrm{AH})$ esquerda com hipersinal em T2. A presença de AH com hipersinal em T2 neste paciente não está até o momento associada com crises refratárias. Conclusões: Apesar de não dispormos de RM previamente ao início do quadro clínico, é provável que esta alteração hipocampal seja decorrente da resposta inflamatória aos cisticercos associadamente às crises parciais repetidas. Isto sugere que formas agudas de neurocisticercose associadas a crises repetidas possam causar EMT e ELT de início tardio.
\end{abstract}

PALAVRAS-CHAVE: epilepsia de lobo temporal, atrofia hipocampal, esclerose mesial temporal, neurocisticercose aguda.

The presence of a cystic parenchimatous lesion of neurocysticercosisis associated to inflammatory response, depending on the patient immunological tolerance. It may remain active and present progres- sive growth, sometimes not associated to clinical manifestation for years ${ }^{1-3}$.

When inflammatory response or excessive enlargement of the cyst comes up, there may be many

Departamento de Neurologia, Faculdade de Ciências Médicas, Universidade Estadual de Campinas (UNICAMP), Campinas SP, Brazil. Supported by FAPESP.

Received 14 September 2000, received in final form 4 December 2000. Accepted 8 December 2000.

Dr. Fernando Cendes, MD, PhD - Departamento de Neurologia - FCM - UNICAMP - Caixa Postal 6111 - $13083-970$ Campinas SP - Brasil.

E-mail: fcendes@unicamp.br 
symptoms, including seizures, headache or focal neurological deficits. The CSF may be normal or show only mild protein elevation, but pleocytosis with presence of eosinophilus and a positive ELISA or immunofluorescence test is commonly observed ${ }^{1-3}$.

The treatment with cysticids (albendazole or praziquantel) in most patients accelerate the degeneration of cysts and improve clinical symptoms ${ }^{3,4}$, but this remains controversial ${ }^{1}$. Neurocysticercosis and seizures are common and its relationship is more clearly identified in patients with adult onset partial seizures, frequently associated to headache or focal neurological deficits. The correlation between cyst localization and seizure semiology is variable, as well as the correlation between number of cysts and seizure frequency $\mathrm{y}^{2,4,5}$.

The recent advances on neuroimaging have provided means for better evaluating patients with epilepsy, particularly those with refractory seizures or suspected structural abnormalities. New MRI techniques have allowed a more detailed evaluation of cystic lesions, inflammatory response (observed as the presence of edema or gadolinium enhancement) and associated abnormalities ${ }^{6}$.
The presence of hippocampal atrophy (HA) associated with altered internal structure and increased T2 signal is an "in vivo" MRI evidence of mesial temporal sclerosis (MTS) ${ }^{7}$. MTS is a particular pathological finding, observed more than a century ago, with a specific pattern of neuronal loss on subfields of hippocampal formation and other medial temporal structures $^{8}$. It has been associated to prolonged febrile seizures and recurrent seizures, but the relationship of repeated seizures and HA remains uncertain?.

The co-existence of HA and neurocysticercosis has been demonstrated, mainly in patients with calcified lesions and history of temporal lobe epilepsy (TLE), with early seizure onset and refractory epilepsy ${ }^{10,11}$. As TLE is the most frequent form of partial epilepsy and neurocysticercosis is highly prevalent among our patients, these calcifications are thought to have an innocent role in the clinical outcome of these patients ${ }^{11,12}$.

We describe in this report the early finding of MRI evidence of MTS in a patient with new onset complex partial seizures (CPS) after acute neurocysticercosis, and we discuss the possible mechanisms in the development of hippocampal pathology.
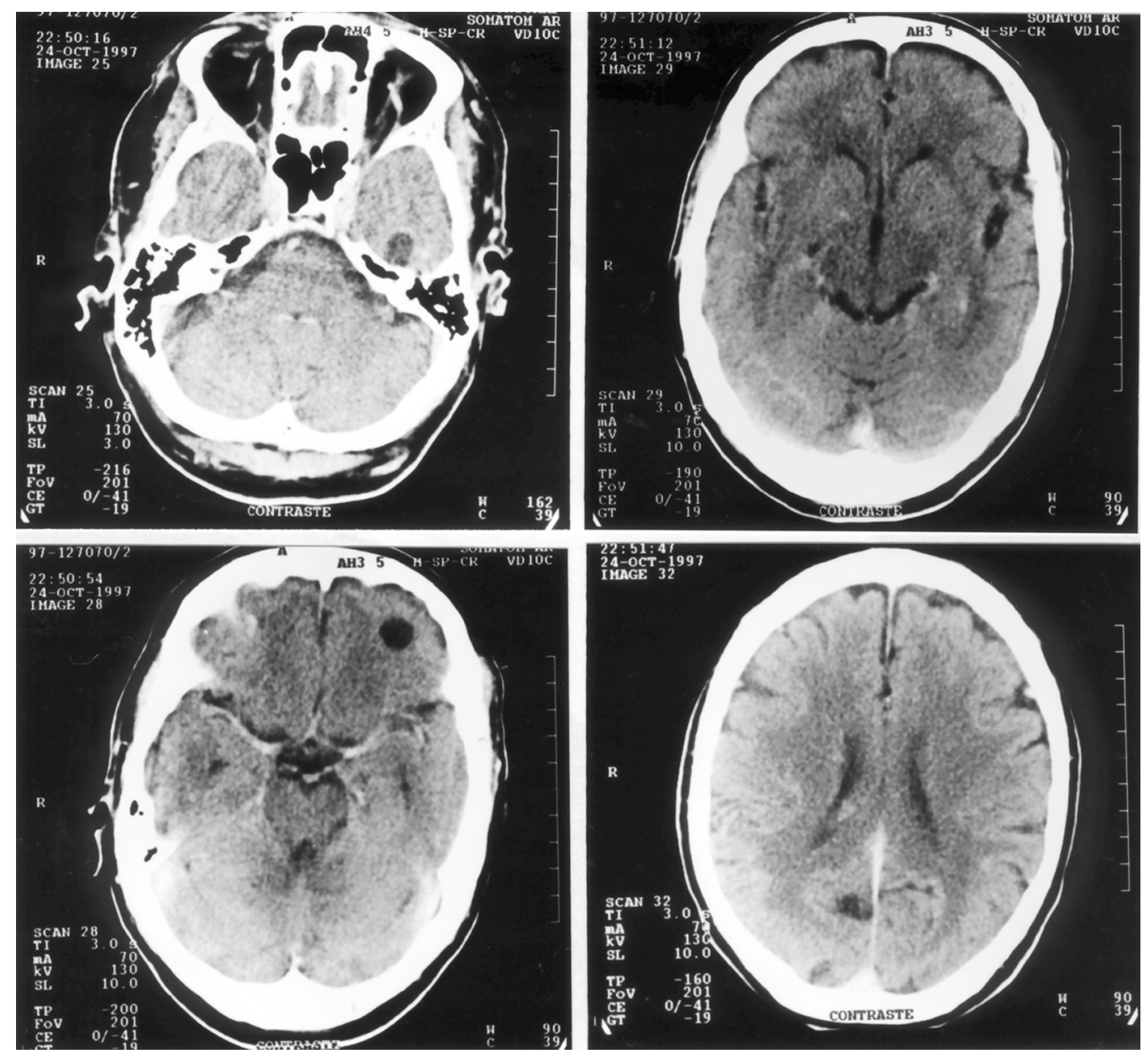

Fig 1. CT scan showing multiple cortical cysts, with contrast enhancement (more evident in the left temporal lobe cyst). 


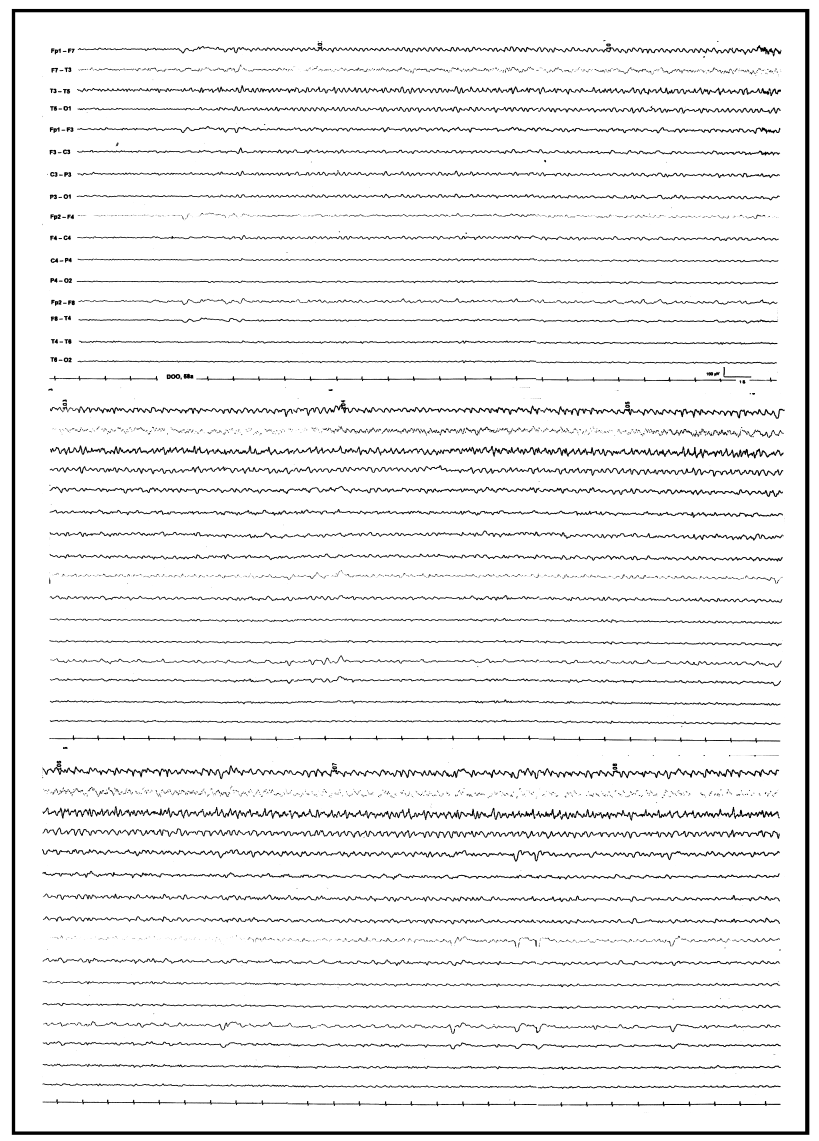

Fig 2. EEG performed during the acute infection, showing a left temporal onset seizure, clinically compatible with complex partial seizure.

\section{CASE}

A 56 years old man came to our emergency room on 10/22/97, with history of pulsatile left headache for 4 days. The headache had an anterior predominance and was associated with scotomas in the left hemifield, with no clinical improvement after analgesics. No significant medical history was identified prior to this, except for tabacco and alcohol use. On neurological examination, no abnormalities were found and he was dispensed with NSAID and asked to return in 2 days for reevaluation.

On reevaluation he referred improvement of the headache, but started having short episodes of malaise, sudoresis, altered responsivity with speech abnormalities. During examination he presented a similar episode, with oromandibullary automatisms and aphasia, lasting for 2 minutes. We prescribed phenytoin infusion and ordered a CT scan.

The CT showed multiple cystic lesions, with contrast enhancement, in the following regions: left frontal, left temporal, right parietal, and right Sylvian fissure (Fig 1).

A lumbar puncture was performed and CSF showed a mild pleocytosis (25 leucocytes: $90 \%$ limphocytes, $4 \%$ neutrophils, $6 \%$ eosinophils) with an increased protein (78 $\mathrm{mg} / \mathrm{dl}$ ) and glucose level (174 mg/dl). IgG level was 12 $\mathrm{mg} / \mathrm{dl}$. EEG showed 2 CPS with ictal onset in the left temporal region, and interictal EEG showed small sharp waves and continuous slow waves in the left temporal region (Fig 2).

We started treatment with prednisone $1 \mathrm{mg} / \mathrm{kg} /$ day and after 5 days he received albendazole $20 \mathrm{mg} / \mathrm{kg} / \mathrm{day}$ for 21 days. The patient continued having seizures once a week for the following 2 months. After this period, he had only sporadic episodes of CPS, the last one in $02 / 98$. He is now on phenobarbital because he developed cutaneous rash related to phenytoin. He has had some episodes of mild headache but no further seizures. Another lumbar puncture was performed on 02/98 and CSF showed 21 leucocytes (100\% limphocytes) and protein of $88 \mathrm{mg} / \mathrm{dL}$.

MRI was performed on 09/98 (11 months after seizure onset) and showed $\mathrm{HA}$, altered internal structure and increased T2 signal (Fig 3). The previously identified cystic lesions on CT disappeared completely and only a small cyst over the right hippocampus, compatible with plexus choroyd cyst, was observed.

\section{DISCUSSION}

TLE is often associated with MTS, particularly in patients with refractory seizures and history of earlier prolonged febrile seizure ${ }^{8}$. Nevertheless, the etiology of MTS remains controversial. The surgical resection of the mesial temporal structures including amygdala and hippocampus in these patients is related to a good outcome, with up to $95 \%$ of patients becoming seizure-free.

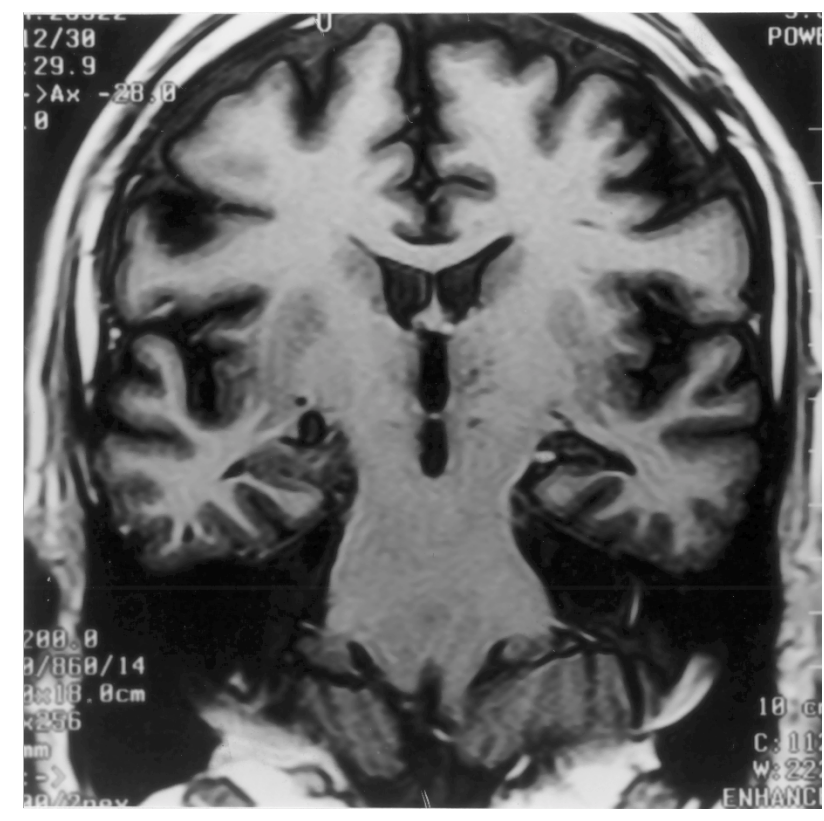

Fig 3. MRI scan performed 11 months after seizure onset, showing complete resolution of the cystic lesions and signs of left hippocampal atrophy. A plexus choroid cyst over the right hippocampus is observed. 
More recently, MRI evaluation of patients with mild TLE, including those with seizure remission or only few episodes, has brought new insights about the causative role of repeated seizures and other environmental factors in the development of $\mathrm{HA}^{13}$. Moreover, the presence of subtle hippocampal abnormalities on asymptomatic individuals has pointed the genetic influence on the epilepsy and the HA in these patients ${ }^{9,13}$.

The epileptogenic role of the cysticercus is thought to be related to the inflammatory response that it carries out ${ }^{11}$. More frequently, the seizure semiology is related to the localization of the cyst ${ }^{14,15}$.

Our patient presented with new onset left temporal lobe seizures during the acute infection of neurocysticercosis and follow-up MRI evidence of MTS. Although it is probable that the acute episode of repeated CPSs induced some neuronal damage, it is most likely that the presence of cysts in the temporal lobe associated with an acute inflammatory response nearby and within the hippocampus played a major role in the development of MTS in this patient.

This suggests that an acute neurocysticercosis infection, associated with repeated CPS may be one etiologic factor in the genesis of MTS and late onset TLE.

\section{REFERENCES}

1. Carpio A, Escobar A, Hauser WA. Cysticercosis and epilepsy: a critical review. Epilepsia 1998;39:1025-1040.

2. Monteiro L, Nunes B, Mendonça D, Lopes J. Spectrum of epilepsy in neurocysticercosis: a long term follow-up of 143 patients. Acta Neurol Scand 1995;92:33-40.

3. Vazquez V, Sotelo J. The course of seizures after treatment for cerebral cysticercosis. New Engl J Med 1992;327:696-701.

4. Santos IC, Kobayashi E, Cardoso TAM, Guerreiro CAM, Cendes F. Cysticidal therapy: impact on seizure control in epilepsy associated with neurocysticercosis. Arq Neuropsiquiatr 2000;58:1014-1020.

5. Kowacs PA, Rogacheski E, Werneck LC. The relevance of temporal lobe as an irritative and symptomatogenic area in epilepsy associated to abnormal intracranial calcifications. Arq Neuropsiquiatr 1998;56 (Supl1): 314 (abstract)

6. Fried I, Kim JH, Spencer DD. Hippocampal pathology in patients with intractable seizures and temporal lobe masses. J Neurosurg 1992;76:735740 .

7. Watson C, Jack CR, Cendes F. Volumetric Magnetic Resonance Imaging. Clinical applications and contribuitions to the understanding of temporal lobe epilepsy. Arch Neurol 1997;54: 1521-1531.

8. Gloor P. Mesial temporal sclerosis: historical background and an overview from a modern perspective. In Lüders H (ed). Epilepsy surgery. New York: Raven Press,1991:689-703.

9. Fernandez G, Effenberger O, Vinz B, et al. Hippocampal malformation as a cause of familial febrile convulsions and hippocampal sclerosis. Neurology 1998; 50: 909-916.

10. Manreza MLG. Epilepsia e neurocisticercose. In Guerreiro, et al. (eds). Epilepsia. 3.E. Lemos editorial, 2000; 255-264.

11. Jorge CL, Valerio RMF, Bueno JF, Guilhoto LMFF, Valente KDR, Yakubian EMT. Mesial temporal sclerosis: related or not to neurocysticercosis? Arq Neuropsiquiatr 1998;56 (Sup11):205.

12. Terra VC, Sakamoto AC, Santos AC, Garzon E, Mendes, MFSG. et al. Epilepsy and cerebral cysticercosis: correlation between CT, EEG and clinical findings. Epilepsia 1995;36(suppl 3):S266.

13. Kobayashi E, Cendes F, Guerreiro CAM, Lopes-Cendes I. MRI abnormalities in familial temporal lobe epilepsy. Neurology 1999 (Suppl 2): A545.

14. Monteiro L, Nunes B, Mendonça D, Lopes J. Spectrum of epilepsy in neurocysticercosis: a long-term follow-up of 143 patients. Acta Neurol Scand 1995;92:33-40.

15. Takayanagui OM. Neurocisticercose I. Evolução clínico-laboratorial em 151 casos. Arq Neuropsiquiatr 1990;48:1-10. 